\title{
IMPROVEMENT IN RELIABILITY INDICES OF A POWER DISTRIBUTION SYSTEM: A CASE STUDY
}

\author{
M. V. Kesavakumar ${ }^{1}$, V. Srihari ${ }^{2}$, B. Sarvesh $^{3}$ \\ ${ }^{1}$ M.Tech. Student of Reliability Engineering at JNTUACEA, Andhra Pradesh, India \\ ${ }^{2}$ Director of SIPRA Labs, Hyderabad, Telangana, India \\ ${ }^{3}$ Professor in EEE Dept., JNTUACEA, Anantapuramu, Andhra Pradesh, India
}

\begin{abstract}
Frequent occurrence of failures is common in Electrical Power Distribution Systems. The consequences of failure include high cost of maintenance, undesirable effects and risks which affect the power consumers. The important goals of reliability and maintainability of distribution systems are availability of continuous power and meeting the load requirements. The Power Distribution System at SIPRA Labs (BALANAGAR FACILITY) consists of three phase and single phase loads. In this work Reliability Analysis is conducted for each component like Miniature Circuit Breaker (MCB), Moulded Case Circuit Breaker $(M C C B)$ and other different components by calculating failure rate and repair rate individually on yearly basis. Mean Time To Failure (MTTF), Mean Time To Repair (MTTR), Mean Time Between Failure (MTBF) of the overall system are calculated from failure rate and repair rate of each component. Customer- and Load-Oriented indices of overall Power Distribution System are predicted from load details, failure rate and Unavailability under each feeder line. MATLAB Programming is developed for overall system reliability analysis.
\end{abstract}

Keywords: Power Distribution System, MCCB \& MCB, Repairable and Non-repairable components

\section{INTRODUCTION}

Electrical Power Distribution System Reliability study is of prime concern to the utilities as power supply quality and maintenance will be affected to the customers connected to the load points. The Power Distribution System is generally radial in nature although parallel or meshed systems can also be adopted. The Distribution System Reliability analysis implies evaluation of basic Probability Indices and Performance Indices. The Performance Indices can also be categorized into Customer Oriented and Load and Energy Oriented Indices. The evaluation of the reliability indices for the power distribution system in the industry (SIPRA labs) is done in this work. Strategies are suggested for improvement in reliability.

In this paper, a practical case study is considered. Existing system is discussed in Section 2. Proposed methodologies and the failure rate calculation for MCCB \& MCB by using MIL-HDBK-217F-Notice2.pdf hand book [1] and Advanced Logistics Software (ALD) [2] are formulated in Section 3. In the proposed system evaluation of Reliability using exponential distribution for each feeder line is presented in Section 3. Algorithm to compute Reliability Indices and Algorithm to use the ALD Software are proposed in Section 4. Illustrations for equivalent failure rate and MTBF calculation for overall distribution system using non repairable model and repairable model are presented in Section 5. These Reliability Indices are computed for an Existing System by using Cut-Set approach. MTBF Values for both repairable [3] and non repairable models [4] [5] are tabulated. A method is proposed in Section 6 to calculate performance Indices like Customer and Load Oriented
Indices [6] for Practical Power Distribution System. Conclusions are presented in Section 7. MATLAB Program has been developed for evaluation of performance Indices like System Average Interruption Duration Index (SAIDI), System Average Interruption Frequency Index (SAIFI), Customer Average Interruption Duration Index (CAIDI), Average Service Availability Index (ASAI), Energy Not Supplied Index (ENSI), Expected Energy Not Supplied (EENSI) [7] [8] and Mean Time Between Failure (MTBF), Mean Time To Failure (MTTF), Mean Time To Repair (MTTR) and Equivalent Failure Rate.

\section{A PRACTICAL SYSTEM: A CASE STUDY}

\subsection{Power Distribution System at SIPRA Labs}

Power Distribution System consists of number of loads such as three phase induction motor, Split Air Conditioners, Air Handling Units (AHU), lighting system and other electronic equipment. These three phase and single phase loads are fed through feeders namely Dog facility, Main building, Rabbit facility, AHU, UPS etc.

The existing system consists of Govt. supply of 400V connected to Stabilizer of 100KVA rating connected through a Fuse box of rating (100A) each. Stabilizer and Distribution Generator (DG) of rating 65KVA are connected in parallel by a Change over Switch (COS).From COS the feeder lines are connected to MCCB's \& MCB's of different ratings. 


\section{PROPOSED METHODOLOGIES}

\subsection{The Failure Rate Calculation for MCCB \& MCB}

Exponential distribution is used in reliability engineering because it has a failure rate which tends to be constant. This distribution has been used to model the lifetime of electronic and electrical components and systems.

Part failure rate model is given by

$$
\lambda_{\mathrm{p}}=\lambda_{\mathrm{b}} * \Pi_{\mathrm{C}} * \Pi_{\mathrm{U}} * \Pi_{\mathrm{Q}} * \Pi_{\mathrm{E}} f / M h r s
$$

Where,

$\lambda_{\mathrm{p}}$ is the part failure rate,

$\lambda_{\mathrm{b}}$ is the base failure rate,

$\pi_{\mathrm{E}}$ is the Environmental factor the other $\pi$ factors modify the base failure rate for category of environmental application and other parameter that affect the part reliability

$>$ Reliability calculations assume as a constant failure rate.

$>$ The failure rates of MCCB \& MCB can be taken from MIL-HDBK-217F-Notice2 hand book.

$>$ The MIL-HDBK-217F hand book data for circuit breaker is taken.

$>\quad$ The failure rate of MCCB and MCB are to be calculated

$>\mathrm{MCCB}$ used is 4PST \& act as a Power On/Off Switch for each feeder.

$>\mathrm{MCB}$ is 2PST \& NOT used as Power On/Off Switch. Quality factor is taken as lower. Advanced Logistic Software (ALD) is used to calculate the failure rate \& MTBF of single Component based on the values given in the MILHDBK-217F Hand book.

The Equivalent failure rate and MTBF can be predicted for the two models

1. Component Non-Repairable Model

2. Component Repairable Model.

\subsection{Component Non-Repairable model}

The MCCB and MCB are non repairable components. So, the Equivalent Failure Rate of Overall system is evaluated by knowing the MTBF.

MTBF of N parallel system (without repairs) is

$$
\operatorname{MTBFp}(N)=\frac{1}{\lambda}\left[1+\frac{1}{2}+\frac{1}{3}+---+\frac{1}{N}\right]
$$

For Series System $\operatorname{MTBFs}(N)=\frac{1}{\sum_{i=1}^{N} \lambda i}$

\subsection{Basic Reliability Indices (Component Repairable} Model)

A cut-set is a set of components that cause a failure to the system when all of the components set to fail. The system does not fail when at least one of the components in the minimal cut-set is working. Let the components $\mathrm{X}$ and $\mathrm{Y}$ connected in parallel and series, as shown in Fig- 1 and 2 respectively.

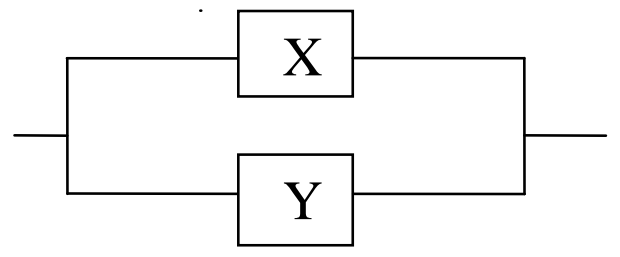

Fig- 1: X \& Y components in parallel

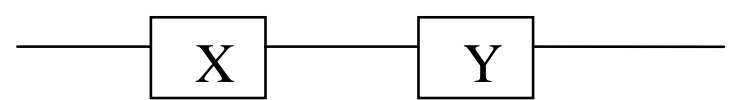

Fig- 2: $X \& Y$ components in series

EquivalentIndicesof componentsin ParallelCut - setare :

Failure rate $=\lambda(\mathrm{X}, \mathrm{Y})=[(\lambda(\mathrm{X}) * \lambda(\mathrm{Y}) *(\mathrm{r}(\mathrm{X})+\mathrm{r}(\mathrm{Y})) / 8760] \mathrm{f} / \mathrm{yr}$.

Repair time $=r(X, Y)=[(r(X) * r(Y)) /(r(X)+r(Y))]$ hrs.

Annualoutagetime $=\mathrm{U}(\mathrm{X}, \mathrm{Y})=(\lambda(\mathrm{X}, \mathrm{Y}) * \mathrm{r}(\mathrm{X}, \mathrm{Y})) \mathrm{hrs} / \mathrm{yr}$.

EquivalentIndicesof componentsin Series Cut - setare :

Failure rate $=\lambda(\mathrm{X}, \mathrm{Y})=\lambda(\mathrm{X})+\lambda(\mathrm{Y}) \mathrm{f} / \mathrm{yr}$.

Annualoutagetime $=\mathrm{U}(\mathrm{X}, \mathrm{Y})=\lambda(\mathrm{X}) * \mathrm{r}(\mathrm{X})+\lambda(\mathrm{Y}) * \mathrm{r}(\mathrm{Y}) \mathrm{hrs} / \mathrm{yr}$.

Repair time $=r(X, Y)=U(X, Y) / \lambda(X, Y)$ hrs .

Where,$\lambda(\mathrm{X})=$ Failure Rate Component $\mathrm{X}$.

$\lambda(\mathrm{Y})=$ Failure Rate Component $\mathrm{Y}$.

$\mathrm{r}(\mathrm{X})=$ Repair Time of component $\mathrm{X}$.

$\mathrm{r}(\mathrm{Y})=$ Repair Time of component $\mathrm{Y}$.

$\lambda(\mathrm{X}, \mathrm{Y})=$ Failure Rate of System

$r(X, Y)=$ Repair Time of thesystem.

AnnualOutageTime $=\mathrm{Up}=\lambda \mathrm{p} * \mathrm{rp}$

EquivalentRepair Time $=R_{p}=1 /\left(\frac{1}{r_{1}}+\frac{1}{r_{2}}+\frac{1}{r_{3}}---+\frac{1}{r_{10}}\right) \ldots \ldots$

\subsubsection{Calculation for MTTF \& MTTR}

If all components are identical and each component has a failure rate of $\lambda$, we obtain,

$$
\operatorname{MTTF} p=\frac{1}{\lambda p} \ldots
$$

Where, $\lambda_{\mathrm{p}}=$ Equivalent Failure Rate. 


$$
\operatorname{MTTR} p=\frac{1}{\mu p} \ldots \ldots
$$

Where, $\mu_{\mathrm{p}}$ is the Equivalent Repair Rate. Its units are repairs per year.

$$
\because r_{p}=\frac{1}{\mu p}
$$

\subsubsection{Formulae for Performance Indices}

$$
\begin{aligned}
\text { SAIFI } & =\frac{\sum_{i=1}^{k} \lambda_{L i} * N_{L i}}{\sum_{i=1}^{k} N_{L i}} \text {.Interruptions/Customer year .....(15) } \\
\text { SAIDI }= & \frac{\sum_{i=1}^{k} U_{L i} * N_{L i}}{\sum_{i=1}^{k} N_{L i}} \text { Hrs/Customer Interruption }
\end{aligned}
$$

Where, $\lambda_{L i}=$ Failure rate for feeder line $\mathrm{i}$,

$N_{L i}=$ No. of Customers under feeder line i,

$U_{L i}=$ Annual Outage Time of feeder line i,

$L_{a i}=$ Load point at feeder line i.

\section{ALGORITHM}

\subsection{Algorithm to Compute Reliability Indices}

1. For the existing system the Single Line Diagram is developed.

2. The load of the system is calculated by taking each component load rating and summing up their individual loads.

3. Feeder Number, Name, Rating and Their Phase Currents are noted.

4. The component failure rate data is obtained. The Probability Logic Diagram (PLD) for each feeder line and the corresponding simplifications are conducted.
5. Similarly, for the other feeder lines the PLD is drawn and the Overall Power Distribution Reliability is computed.

6. Number of parallel components, series components for each feeder line, Reliability for each feeder line and Equivalent Parallel Feeder Lines are identified.

7. Since the MCCB \& MCB are non-repairable components the Equivalent Failure Rate is predicted.

8. The MTBF and Failure Rate values for each feeder line are evaluated.

9. The repair times are assumed and Equivalent Failure Rate is predicted by using cut-set based approach. MTTF and MTTR are calculated.

10. MTBF for the System with repair and non-repairable model are computed.

11. Loads under each feeder line are calculated and the Number of Customers under each feeder line is calculated to predict Performance Indices.

\subsection{Algorithm to use the ALD Software}

1. Select the Component family, whether the Component belongs to Electronic or Mechanical.

2. Select the name of the component (Circuit Breaker here).

3. Select Method of Reliability Prediction (MIL-217F-2 Part Stress here).

4. Select the type of Environment and note the Temperature.

5. Press the 'calculate' button (initially the values of MTBF and failure rate are zero).

6. A new window will open which consists of the type of Circuit Breaker, Configuration, Application, Quality and then press 'OK' button.

Again the first window will open which gives the values of Failure rate in failure per million hour and MTBF in hours at the right bottom end. The Single Line Diagram for Distribution System is shown in Fig- 3. In this Single Line Diagram there are 10 feeder lines denoted as $F_{1}, F_{2},----, F_{10}$. 


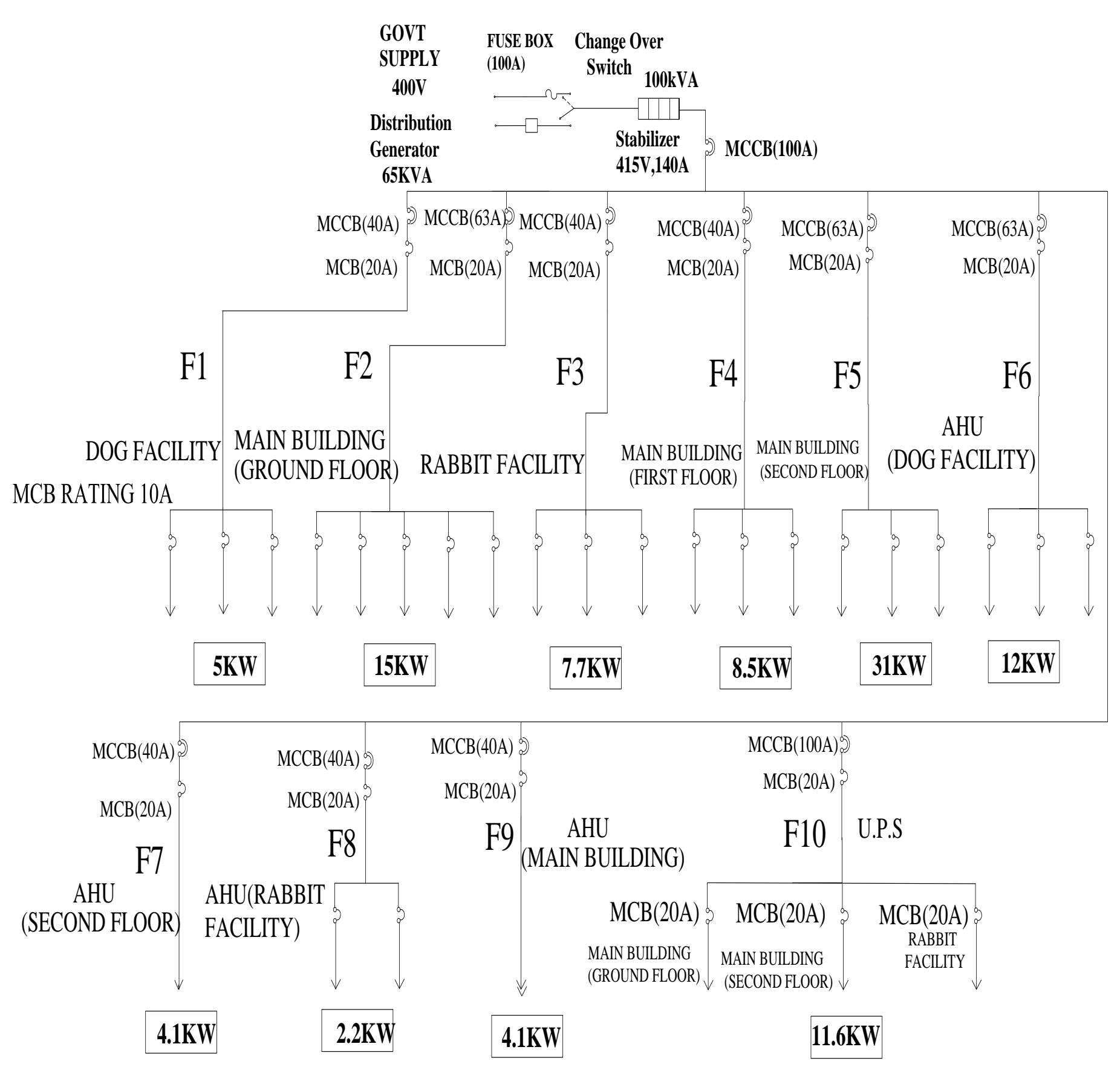

Fig- 3: Single Line Diagram 


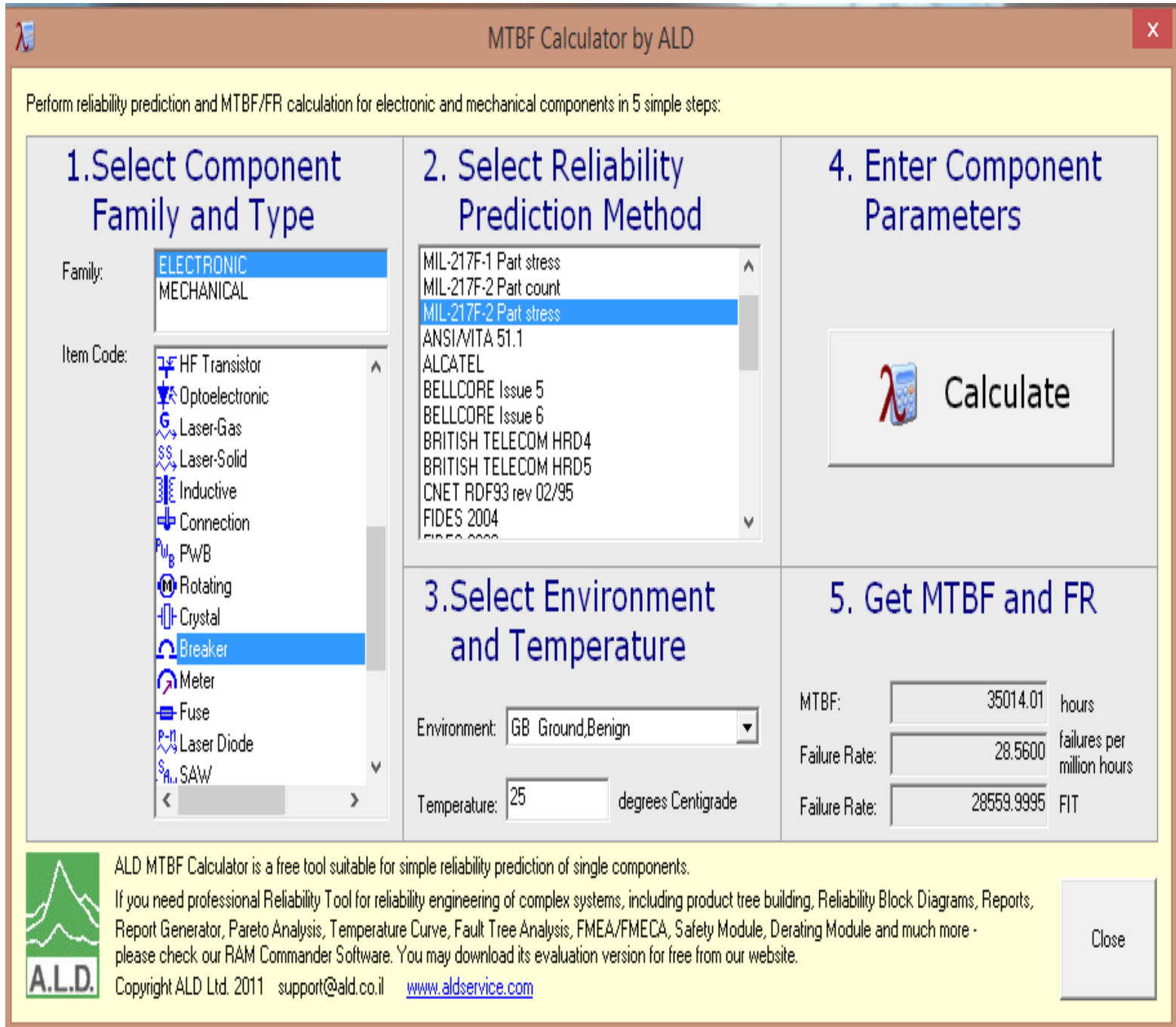

Fig- 4 Screen Shot of ALD Software

The screen shot of ALD Software is shown in Fig- 4, which shows the failure rate of MCCB in failures per million hour and MTBF in hours. The Current ratings of each phase under each Feeder Line are shown in Table- 1.

Table- 1: Feeder Number, Name, Rating and Their Phase

\begin{tabular}{|l|l|l|l|l|l|}
\hline $\begin{array}{l}\text { FEE } \\
\text { DER } \\
\text { NO. }\end{array}$ & $\begin{array}{l}\text { FEEDER } \\
\text { NAMES }\end{array}$ & $\begin{array}{l}\text { MCCB } \\
\text { CURRE } \\
\text { NT } \\
\text { RATING } \\
\text { (A) }\end{array}$ & $\begin{array}{l}\text { R } \\
\text { phase } \\
(\mathrm{A})\end{array}$ & $\begin{array}{l}\text { Y } \\
\text { pha } \\
\text { se } \\
(\mathrm{A})\end{array}$ & $\begin{array}{l}\text { B } \\
\text { phase } \\
(\mathrm{A})\end{array}$ \\
\hline F1 & $\begin{array}{l}\text { DOG } \\
\text { FACILITY }\end{array}$ & 40 & 8 & 8.6 & 8.3 \\
\hline F2 & $\begin{array}{l}\text { MAIN } \\
\text { BUILDING } \\
\text { (GROUND } \\
\text { FLOOR) }\end{array}$ & 63 & 11 & 11.2 & 11.3 \\
\hline F3 & $\begin{array}{l}\text { RABBIT } \\
\text { FACILITY }\end{array}$ & 40 & 9.4 & 9.5 & 9.2 \\
\hline F4 & $\begin{array}{l}\text { MAIN } \\
\text { BUILDING( } \\
\text { FIRST }\end{array}$ & 40 & 10.6 & 10 & 10.8 \\
\hline
\end{tabular}

\begin{tabular}{|l|l|l|l|l|l|}
\hline & FLOOR) & & & & \\
\hline F5 & $\begin{array}{l}\text { MAIN } \\
\text { BUILDING( } \\
\text { SECOND } \\
\text { FLOOR) }\end{array}$ & 63 & 15.8 & 15.8 & 15.1 \\
\hline F6 & $\begin{array}{l}\text { AHU(DOG } \\
\text { FACILITY) }\end{array}$ & 63 & 13.5 & 13.6 & 13.2 \\
\hline F7 & $\begin{array}{l}\text { AHU(SECO } \\
\text { ND FLOOR) }\end{array}$ & 40 & 5 & 5.6 & 6.5 \\
\hline F8 & $\begin{array}{l}\text { AHU(RABB } \\
\text { IT } \\
\text { FACILITY) }\end{array}$ & 40 & 4 & 5.1 & 4.2 \\
\hline F9 & $\begin{array}{l}\text { AHU(MAIN } \\
\text { BUILDING) }\end{array}$ & 40 & 6.6 & 5.9 & 5.3 \\
\hline F10 & $\begin{array}{l}\text { UPS } \\
\text { SYSTEM }\end{array}$ & 100 & 12.1 & 12.2 & 13.6 \\
\hline & $\begin{array}{l}\text { TOTAL } \\
\text { AMPS }\end{array}$ & $\mathbf{9 6}$ & $\mathbf{9 7 . 5}$ & $\mathbf{9 7 . 5}$ \\
\hline
\end{tabular}

From the Eqns (1), (2) failure rate and MTBF values are predicted respectively for MCCB \& MCB: 
For MCCB:

Failure rate per million hours $=28.56$ failures per million hours

Mean Time Between failure $=35014.01$ hours

For MCB:

Failure rate per million hours $=5.120$ failures per million hours

Mean Time Between failure $=175070.03$ hours

From these it can be deduced that the MTBF for the Circuit Breaker (MCB) is 20 years and MCCB is 4 years approximately.

\section{RELIABILITY AND FAILURE RATE}

\section{IMPROVEMENT}

\subsection{Reliability Analysis for Each Feeder Line}

\subsubsection{Reliability Analysis for Feeder Line 1}

For the reliability analysis to the overall system each feeder line is taken. The feeder line 1 and its components are shown in Fig 5.1 (a) and the corresponding simplification is shown in Fig 5.1 (b) and (c).

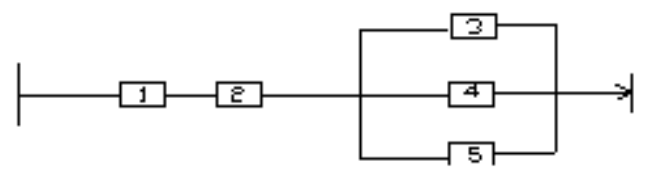

Fig- 5.1(a) Feeder Line 1 and its Components

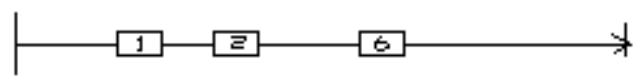

Fig- 5.1(b)

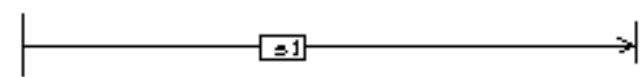

Fig- 5.1(c)

Fig- 5.1(b) and (c) Simplification

$\mathrm{Q}_{6}=\mathrm{Q}_{3} * \mathrm{Q}_{4} * \mathrm{Q}_{5}=\mathrm{Q}^{3} \quad$ Since, $\mathrm{Q}_{3}=\mathrm{Q}_{4}=\mathrm{Q}_{5}=\mathrm{Q}$

$\mathrm{Rs}_{1}=\mathrm{R}_{1} * \mathrm{R}_{2} * \mathrm{R}_{6}$

$\mathrm{Rs}_{1}=\mathrm{R}_{1} * \mathrm{R}_{2} *\left(1-\mathrm{Q}^{3}\right)$

$\mathrm{Rs}_{1}=\mathrm{R}_{1} *\left[(1-\mathrm{Q}) *\left(1-\mathrm{Q}^{3}\right)\right]$

Feeder line 1 Reliability $=\mathbf{R s}_{\mathbf{1}}=\mathbf{0 . 7 4 0 7 3 2}$.

\subsubsection{Reliability Analysis for Feeder Line 2}

The feeder line 2 and its components are shown in Fig 5.2 (a) and the corresponding simplification is shown in Fig 5.2 (b) and (c).

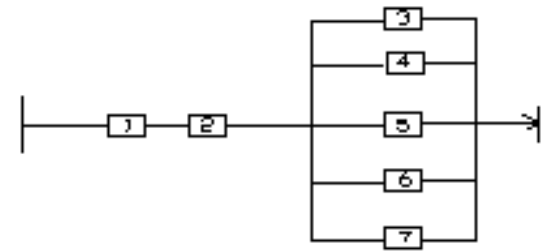

Fig- 5.2(a) Feeder Line $2 \&$ its Components

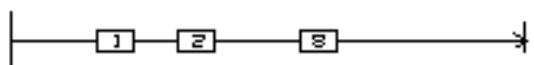

Fig- 5.2(b)

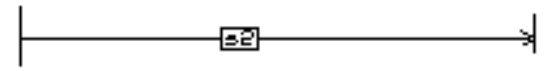

Fig- 5.2(c)

Fig- 5.2(a) and (c): Simplification

$\mathrm{Q}_{8}=\mathrm{Q}_{3} * \mathrm{Q}_{4} * \mathrm{Q}_{5} * \mathrm{Q}_{6} * \mathrm{Q}_{7}=\mathrm{Q}^{5}$

$\mathrm{Rs}_{2}=\mathrm{R}_{1} * \mathrm{R}_{2} * \mathrm{R}_{8}$

$\mathrm{Rs}_{2}=\mathrm{R}_{1} *(1-\mathrm{Q}) *\left(1-\mathrm{Q}^{5}\right)$

Similarly, $\quad \mathrm{Rs}_{2}=0.740818$.

Feeder line 2 Reliability $=\mathbf{R s}_{\mathbf{1}}=\mathbf{0 . 7 4 0 8 1 8}$

The other Feeder lines are come under the same configuration. Hence, simplification is not shown. The overall reliability of each Feeder line is shown in Table- 2. Overall Parallel feeder line after simplifying is shown in Fig- 6.1(a) and 6.1(b).

Table- 2: Reliability for each Feeder Line

\begin{tabular}{|l|l|l|l|}
\hline $\begin{array}{l}\text { Feeder } \\
\text { Line } \\
\text { No. }\end{array}$ & $\begin{array}{l}\text { No. of } \\
\text { Parallel } \\
\text { Components }\end{array}$ & $\begin{array}{l}\text { Overall Series } \\
\text { Components } \\
\text { for each } \\
\text { Feeder Line }\end{array}$ & $\begin{array}{l}\text { Over All } \\
\text { Reliability } \\
\text { for Each } \\
\text { Feeder } \\
\text { Line }\end{array}$ \\
\hline 3 & 3 & 3 & 0.740732 \\
\hline 4 & 3 & 3 & 0.740732 \\
\hline 5 & 3 & 3 & 0.740732 \\
\hline 6 & 3 & 3 & 0.740732 \\
\hline 7 & 0 & 2 & 0.740818 \\
\hline 8 & 2 & 3 & 0.739056 \\
\hline 9 & 0 & 2 & 0.740818 \\
\hline 10 & 3 & 3 & 0.740732 \\
\hline
\end{tabular}

\subsection{Overall Parallel Feeder Lines:}

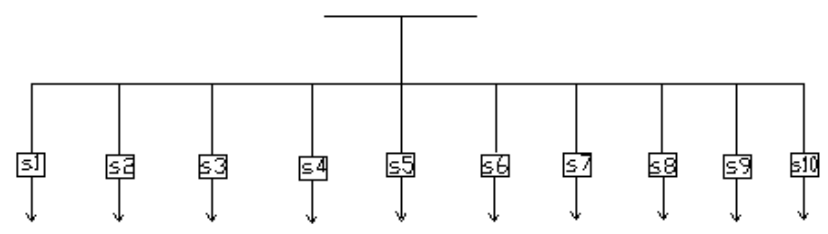

Fig- 6.1(a): Equivalent Parallel Feeder Lines

And their simplification shown in Fig- 5.3(b) 


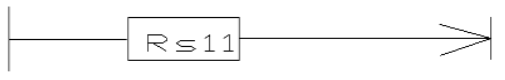

Fig- 6.1(b) Simplification

Fig- 6: Overall Parallel Feeders Reliability

$$
\begin{gathered}
\mathrm{Qs}_{11}=\left(1-\mathrm{Rs}_{1}\right) *\left(1-\mathrm{Rs}_{2}\right) *\left(1-\mathrm{Rs}_{3}\right) *\left(1-\mathrm{Rs}_{4}\right) *\left(1-\mathrm{Rs}_{5}\right) *\left(1-\mathrm{Rs}_{6}\right) *(1- \\
\left.\mathrm{Rs}_{7}\right) *\left(1-\mathrm{Rs}_{8}\right) *\left(1-\mathrm{Rs}_{9}\right) *\left(1-\mathrm{Rs}_{10}\right)
\end{gathered}
$$

Therefore,

OVER ALL RELIABILITY OF POWER DISTRIBUTION SYSTEM

$\mathrm{Rs}_{11}=\mathbf{0 . 9 9 9 9 9 9}$

\subsection{Calculation of MTBF \& Equivalent Failure Rate}

\subsubsection{Non-Repairable Model:}

MTBF value of MCB is obtained as 20 years and the MCCB as 4 years from Eqn (1). From Eqns (2) and (3) the calculations are as follows,

Failure rate analysis for feeder line 1:

$\operatorname{MTBF}_{6}=\frac{1}{0.05}\left[1+\frac{1}{2}+\frac{1}{3}\right]=36.67$ years

$$
M T B F S_{1}=3.055 \text { years }
$$

$$
\therefore \lambda s 1=0.327 \mathrm{f} / \text { year } \text {. }
$$

The calculations are done similarly for all the feeder lines. MTBF and Failure rate are shown in Table- 3 for feeders from 2 to 10

Table- 3: MTBF \& Failure rate values for each Feeder Line

\begin{tabular}{|l|l|l|}
\hline Feeder Name & $\begin{array}{l}\text { MTBF } \\
\text { (years) }\end{array}$ & $\begin{array}{l}\text { Failure rate } \\
\text { (f/year) }\end{array}$ \\
\hline$F_{2}$ & 3.115 & 0.321 \\
\hline$F_{3}$ & 3.055 & 0.327 \\
\hline$F_{4}$ & 3.055 & 0.327 \\
\hline$F_{5}$ & 3.055 & 0.327 \\
\hline$F_{6}$ & 3.055 & 0.327 \\
\hline$F_{7}$ & 3.030 & 0.334 \\
\hline$F_{8}$ & 3.000 & 0.333 \\
\hline$F_{9}$ & 3.030 & 0.334 \\
\hline$F_{10}$ & 3.055 & 0.327 \\
\hline
\end{tabular}

From the failure rate obtained for each feeder line the Average failure rate is calculated as 0.32 failures/year.

$$
\text { MTBF }=\frac{1}{0.320}\left[1+\frac{1}{2}+---+\frac{1}{10}\right]=9.0122 \text { years }
$$

$\therefore \lambda e q=0.109 f /$ year .

\subsubsection{Repairable Model}

Assume the MCCB \& MCB as repairable components.

Repair time of MCCB is taken as $\mathrm{r}_{\mathrm{MCCB}}=6 \mathrm{hrs}$

Repair time of MCB is taken as $\mathrm{r}_{\mathrm{MCB}}=8 \mathrm{hrs}$

Using the Eqns [(4) - (9)] the calculations for the feeder lines are as follows:

Failure rate of feeder $F_{1}=\lambda s_{1}=\lambda_{1}+\lambda_{2}+\lambda_{6}$

Annual outage time $=\mathrm{Us}_{1}=\lambda_{1} * \mathrm{r}_{1}+\lambda_{2} * \mathrm{r}_{2}+\lambda_{6} * \mathrm{r}_{6}$

Repair time

$=\mathrm{rs}_{1}=\left(\mathrm{Us}_{1} / \lambda \mathrm{s}_{1}\right)$

Therefore,

Annual outage time of feeder line $1=\mathrm{Us}_{1}=1.9 \mathrm{hrs} / \mathrm{yr}$

Equivalent Repair time of feeder line $1=\quad \mathrm{rs}_{1}=6.33 \mathrm{hrs}$

Equivalent failure rate of feeder line $1=\lambda \mathrm{s}_{1}=0.3 \mathrm{f} / \mathrm{yr}$

Similar calculation have shown that Annual Outage Time, Equivalent Repair Time, Equivalent Failure Rate are same for all the other feeder lines. The above values for Overall Power Distribution System are predicted from Eqns (10), (11).

Therefore,

Annual outage time of overall distribution system

$$
\mathrm{U}_{\mathrm{p}}=0.069 \mathrm{hrs} / \mathrm{yr} \text {. }
$$

Annual repair time of overall distribution system

$$
\mathrm{R}_{\mathrm{p}}=0.633 \mathrm{hrs}
$$

Failure rate of overall distribution system

$$
\lambda_{\mathrm{p}}=\mathrm{U}_{\mathrm{p}} / \mathrm{R}_{\mathrm{p}}=0.109 \mathrm{f} / \mathrm{yr} \text {. }
$$

Equivalent Failure Rate for Power Distribution System is $\lambda_{\mathrm{p}}=0.109 \mathrm{f} / \mathrm{yr}$ and MTTF, MTTR, repair times are calculated for overall distribution system having failure rate as 0.3 for each feeder line from the Eqns (12), (13), (15) respectively. For different repair times the values of MTTF, MTTR, MTBF are shown in Table- 4.

The MTBF values for Repairable and Non-Repairable models are shown in Table- 5, Acquired results are as follows:'

$\mathrm{MTTF}=9.174 \mathrm{yrs}=80366 \mathrm{hrs}$

MTTR $=0.633 \mathrm{yrs}=5545.08 \mathrm{hrs}$

Repair rate $\mu=1.579$ repairs/ year

Since, $\quad \mathrm{MTBF}=\mathrm{MTTF}+\mathrm{MTTR}$

$\mathrm{MTBF}=9.807 \mathrm{yrs}$. 
Table-4: MTTF, MTTR, MTBF Values for different Repair times

\begin{tabular}{|c|c|c|c|c|c|c|c|}
\hline \multicolumn{2}{|c|}{$\begin{array}{l}\text { REPAIR } \\
\text { TIME (hrs) }\end{array}$} & \multirow{2}{*}{$\begin{array}{l}\text { Annual } \\
\text { outage } \\
\text { time } \\
(\mathrm{hrs} / \mathrm{yr})\end{array}$} & \multirow{2}{*}{$\begin{array}{l}\text { Equivalent } \\
\text { Repair } \\
\text { time } \\
\text { (hrs) } \\
\end{array}$} & \multirow{2}{*}{$\begin{array}{l}\text { Equivalent } \\
\text { failure } \\
\text { rate } \\
\text { (f/yr) }\end{array}$} & \multirow[b]{2}{*}{$\begin{array}{l}\text { MTTF } \\
\text { (hrs) }\end{array}$} & \multirow[b]{2}{*}{$\begin{array}{l}\text { MTTR } \\
\text { (hrs) }\end{array}$} & \multirow[b]{2}{*}{$\begin{array}{l}\text { MTBF } \\
(\mathrm{hrs})\end{array}$} \\
\hline МСCB & $\mathrm{MCB}$ & & & & & & \\
\hline 8 & 10 & 1.08 & 0.833 & 1.3 & 6738 & 7299 & 14037 \\
\hline 10 & 12 & 9.35 & 1.03 & 9.05 & 967.95 & 9022.8 & 9990 \\
\hline
\end{tabular}

Table-5: MTBF values for repairable and Non-Repairable components

\begin{tabular}{|l|l|}
\hline \multicolumn{2}{|l|}{ MTBF (years) } \\
\hline $\begin{array}{l}\text { Non-Repairable } \\
\text { Model }\end{array}$ & Repairable Model \\
\hline 9.0122 & 9.807 \\
\hline
\end{tabular}

Table- 4 shows that as the repair time increases failure rate increases and MTBF decreases. From Table- 5, it is observed that MTBF increases for repairable model as compared to that of non-repairable model. In other words, the MTBF indicates the operating time and it can be concluded that the components are repairable, and then operating time of the system increases for repairable model. Hence, Performance Indices can be computed.

\section{PERFORMANCE INDICES}

SAIFI, SAIDI, CAIDI, CAIFI, ASAI, ENSI and EENSI are some of the indices used to measure distribution system reliability. These indices are based on the duration of each interruption of power supply and the frequency of interruption. As far as the consumer is concerned, distribution outages are very important. Failure rate and Annual outage time of each feeder line are already calculated in the above Sections. The load and number of customer details shown in Table- 6 and are used to calculate the Performance Indices from the Eqns [(15)-(21)]. These Indices are calculated for different repair times were shown in Table- 7.

Table-6: Number of customers and load details under each Feeder line

\begin{tabular}{|l|l|l|}
\hline $\begin{array}{l}\text { FEEDER } \\
\text { NUMBER }\end{array}$ & $\begin{array}{l}\text { NO.OF } \\
\text { CUSTOMERS } \\
\left(\mathrm{N}_{\mathrm{Li}}\right)\end{array}$ & LOAD(KW) \\
\hline $\mathrm{F}_{1}$ & 3 & 4.9 \\
\hline $\mathrm{F}_{2}$ & 4 & 15 \\
\hline $\mathrm{F}_{3}$ & 4 & 7.6 \\
\hline $\mathrm{F}_{4}$ & 2 & 8.5 \\
\hline $\mathrm{F}_{5}$ & 5 & 30 \\
\hline $\mathrm{F}_{6}$ & 4 & 12 \\
\hline $\mathrm{F}_{7}$ & 2 & 4.1 \\
\hline $\mathrm{F}_{8}$ & 3 & 2.2 \\
\hline $\mathrm{F}_{9}$ & 2 & 4.1 \\
\hline $\mathrm{F}_{10}$ & 6 & 9.6 \\
\hline TOTAL & $\mathbf{3 5}$ & $\mathbf{9 8}$ \\
\hline
\end{tabular}

Table-7: Customer and Load oriented indices for different repair times

\begin{tabular}{|c|c|c|c|c|c|c|c|c|}
\hline \multicolumn{2}{|c|}{$\begin{array}{l}\text { REPA } \\
\text { IR } \\
\text { TIME } \\
\text { (hrs) } \\
\end{array}$} & \multirow[t]{2}{*}{$\begin{array}{l}\text { S } \\
\text { AI } \\
\text { FI }\end{array}$} & \multirow[t]{2}{*}{$\begin{array}{l}\text { SA } \\
\text { ID } \\
\text { I }\end{array}$} & \multirow[t]{2}{*}{$\begin{array}{l}\text { CAI } \\
\text { DI }\end{array}$} & \multirow[t]{2}{*}{$\begin{array}{l}\mathbf{A S A} \\
\text { I }\end{array}$} & \multirow[t]{2}{*}{ ASUI } & \multirow[t]{2}{*}{$\begin{array}{l}\text { EN } \\
\text { SI }\end{array}$} & \multirow[t]{2}{*}{$\begin{array}{l}\text { E } \\
\text { E } \\
\text { NS } \\
\text { I }\end{array}$} \\
\hline $\begin{array}{l}\text { M } \\
\text { C } \\
\text { C } \\
\text { B }\end{array}$ & $\begin{array}{l}\text { M } \\
\text { C } \\
\text { B }\end{array}$ & & & & & & & \\
\hline 6 & 8 & $\begin{array}{l}0 . \\
3\end{array}$ & 1.9 & 6.33 & $\begin{array}{l}0.99 \\
97\end{array}$ & $\begin{array}{l}0.000 \\
21\end{array}$ & $\begin{array}{l}186 . \\
2\end{array}$ & $\begin{array}{l}5.3 \\
2\end{array}$ \\
\hline 8 & $\begin{array}{l}1 \\
0 \\
\end{array}$ & $\begin{array}{l}0 . \\
3 \\
\end{array}$ & 2.5 & $\begin{array}{l}8.33 \\
3 \\
\end{array}$ & $\begin{array}{l}0.99 \\
97 \\
\end{array}$ & $\begin{array}{l}0.000 \\
28 \\
\end{array}$ & 245 & 7 \\
\hline $\begin{array}{l}1 \\
0\end{array}$ & $\begin{array}{l}1 \\
2\end{array}$ & $\begin{array}{l}0 . \\
3\end{array}$ & 3.1 & $\begin{array}{l}10.3 \\
3\end{array}$ & $\begin{array}{l}0.99 \\
96\end{array}$ & $\begin{array}{l}0.000 \\
35\end{array}$ & $\begin{array}{l}303 . \\
8\end{array}$ & $\begin{array}{l}8.6 \\
8\end{array}$ \\
\hline
\end{tabular}

From the Table- 7, it is observed that as the repair time increases the Customer and Load oriented indices increase which reveals that there is decrease in Reliability \& Availability.

\section{CONCLUSION}

In this paper, based on the survey made at SIPRA Labs, all the individual loads are calculated under each feeder line. For the Single line diagram Reliability analysis is conducted for each component like MCB, MCCB by calculating failure rate and MTBF individually on yearly basis. Using cut-set-based approach basic reliability indices for overall distribution system are calculated for different repair times. MTTF, MTTR and repair rate are calculated. MTBF was calculated for Non repairable model as well as Repairable model. From the results repair times of the components are deduced. MATLAB program has been developed for reliability analysis, calculation of reliability indices, MTTF, MTTR calculation and Customer- \& Energy- oriented indices. From the results of failure rate calculation it can be concluded that the reliability of protection system is better when there are radial feeders to the distribution system since these feeders have shown lesser failure rate. It can also be concluded that as the repair time increases there will be increase in failure rate, Unavailability and decrease in MTBF. 


\section{REFERENCES}

[1] Hand book for reliability prediction or electrical and electronic components MIL-HDBK-217F 2 December 1991.

[2] www.aldservice.com for ALD Software.

[3] http://www.mathpages.com/home/kmath326/kmath32 6.htm.

[4] V. Sankar. System Reliability Concepts Himalaya Publications House 2015.

[5] Yang J, Hwang M, Sung T, Jin Y. Reliability Engineering \& System Safety 1999.

[6] R. Billinton, S. Kumar, N. Chowdhury, K. Chu, K. Debnath, L. Goel, E. Khan, P. Kos, G. Nourbakhsh, J. Oteng-Adjei, "A reliability test system for educational purpose-basic data", IEEE Trans. Power Syst., Vol. 4, No. 3, pp.1238-1244,Aug. 1989.

[7] R. Billinton and R. N. Allan, Reliability Evaluation of Power Systems. New York: Plenum, Second Indian Reprint, 2007.

[8] Power Systems Engineering Committee, "IEEE reliability test system," IEEE Trans. on Power apparatus and Systems, vol. 14, pp. 1010-1020, 1999. 